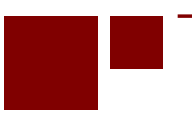

C E N T E R for RETIREMENT RE S E A R C H at BOSTON COLLEGE

\title{
THE RELATIONSHIP BETWEEN AUTOMATIC ENROLLMENT AND DC PLAN CONTRIBUTIONS: EVIDENCE FROM A NATIONAL SURVEY OF OLDER WORKERS
}

\author{
Barbara A. Butrica and Nadia S. Karamcheva
}

CRR WP 2015-14

July 2015

\author{
Center for Retirement Research at Boston College \\ Hovey House \\ 140 Commonwealth Avenue \\ Chestnut Hill, MA 02467 \\ Tel: 617-552-1762 Fax: 617-552-0191 \\ http://crr.bc.edu
}

Barbara A. Butrica is a senior research associate at the Urban Institute. Nadia S. Karamcheva is an analyst at the Congressional Budget Office. The research reported herein was performed pursuant to a grant from the U.S. Social Security Administration (SSA) funded as part of the Retirement Research Consortium. The opinions and conclusions expressed are solely those of the authors and do not represent the opinions or policy of SSA, any agency of the federal government, the Urban Institute, the Congressional Budget Office, or Boston College. Neither the United States Government nor any agency thereof, nor any of their employees, makes any warranty, express or implied, or assumes any legal liability or responsibility for the accuracy, completeness, or usefulness of the contents of this report. Reference herein to any specific commercial product, process or service by trade name, trademark, manufacturer, or otherwise does not necessarily constitute or imply endorsement, recommendation or favoring by the United States Government or any agency thereof. The authors would like to thank Jack VanDerhei and the participants of the 2014 Annual Meeting of the Retirement Research Consortium for valuable comments and suggestions. All errors are their own.

(C) 2015, Barbara A. Butrica and Nadia S. Karamcheva. All rights reserved. Short sections of text, not to exceed two paragraphs, may be quoted without explicit permission provided that full credit, including $@$ notice, is given to the source. 


\begin{abstract}
About the Center for Retirement Research
The Center for Retirement Research at Boston College, part of a consortium that includes parallel centers at the University of Michigan and the National Bureau of Economic Research, was established in 1998 through a grant from the Social Security Administration. The Center's mission is to produce first-class research and forge a strong link between the academic community and decision-makers in the public and private sectors around an issue of critical importance to the nation's future. To achieve this mission, the Center sponsors a wide variety of research projects, transmits new findings to a broad audience, trains new scholars, and broadens access to valuable data sources.
\end{abstract}

Center for Retirement Research at Boston College

Hovey House

140 Commonwealth Ave

Chestnut Hill, MA 02467

Tel: 617-552-1762 Fax: 617-552-0191

http://crr.bc.edu

Affiliated Institutions:

The Brookings Institution

Massachusetts Institute of Technology

Syracuse University

Urban Institute 


\begin{abstract}
Automatic enrollment has been widely embraced for raising employee participation in 401(k) plans. However, the empirical evidence is based on data with limitations that, up until now, have prevented researchers from extrapolating the effects of automatic enrollment to the broader population of workers. This paper reexamines the determinants of 401(k) participation and contributions in the presence of automatic enrollment using nationally representative data from the Health and Retirement Study (HRS) for 2006 through 2012. The results confirm previous findings that automatic enrollment is associated with a higher proportion of workers included in DC plans; however, automatically enrolled workers are less likely to contribute to their DC plans than voluntarily enrolled workers. Auto enrollment is also associated with lower employee contribution amounts and rates. However, the employers of auto-enrolled workers are more likely to contribute to their employees' accounts than are the employers of voluntarily enrolled workers. Additionally, employer contribution amounts and rates are higher among workers who are automatically enrolled. Even so, the combined effect is that the retirement accounts of automatically enrolled older workers receive, on average, \$900 less in combined annual contributions and have contribution rates that are 1.6 percentage points lower than those of voluntarily enrolled workers.
\end{abstract}

The paper found that:

- Automatic enrollment is associated with a higher probability of being included in a DC plan.

- On average, workers who are automatically enrolled in a DC plan tend to be less likely to contribute positive amounts than those who opt in.

- However, the employers of automatically enrolled workers are more likely to make contributions and to contribute, on average, higher amounts and a higher percentage of their employees' earnings.

- The correlation between automatic enrollment and combined (employer and employee) contribution amounts and contribution rates, however, is still negative, despite controlling for a range of factors. 
The policy implications of the findings are:

- Auto enrollment could do a better job of boosting overall contribution levels among participants.

- Possible ways to achieve this might be by offering a more generous employer match and by using auto escalation.

- More research and better data are needed to assess the potential impact on retirement plan contributions of implementing automatic enrollment features in DC plans on a national scale. 


\section{Introduction}

As defined contribution (DC) plans have grown in popularity, so has concern about the retirement security they will provide. Using various data sources, including household surveys, employer-provided plan data, and administrative records of earnings and contributions, previous studies have established that participation, contributions, and accumulations in tax-deferred retirement accounts are concentrated predominantly among higher-income individuals (Bassett, Fleming and Rodrigues 1998; Dworak-Fisher 2011; Dushi, Iams and Tamborini 2011; Karamcheva and Sanzenbacher 2010). These findings have sounded alarms about growing retirement income inequality and stimulated debate about the best ways of boosting DC plan participation and contributions.

Previous research has demonstrated that automatic enrollment is associated with significant increases in 401(k) plan participation and is particularly effective for workers who otherwise would not participate (Beshears et al. 2010; Choi et al. 2002, 2004; Madrian and Shea 2001). However, the empirical evidence is based on data with limitations that have prevented researchers from extrapolating the effects of automatic enrollment to the broader population of workers.

This paper reexamines the determinants of DC plan participation and contributions in the presence of automatic enrollment using data that is nationally representative of older workers and also includes detailed information about their characteristics and economic circumstances. Consistent with other studies, the results show that automatic enrollment is associated with a higher proportion of older workers included in DC plans-particularly short-tenure workers and the lowest earners. Something not highlighted in other studies, however, is the relationship between automatic enrollment and total DC contributions. Controlling for a number of different factors, we find that automatic enrollment is associated with a lower likelihood that older workers will contribute to their DC plans. As a result, employee contribution amounts and contribution rates are lower among those who report having been automatically enrolled, compared with those who were given a choice to enroll. However, we also find that automatic enrollment is associated with an increased probability that older workers' employers will contribute to their plans. As a result, employer contribution amounts and contribution rates are higher among auto enrolled workers than voluntarily enrolled workers. Because the higher employer contributions are not high enough to offset the lower employee contributions, the 
combined effect is that the retirement accounts of automatically enrolled older workers receive, on average, \$900 less in annual total contributions and have 1.6 percentage points lower total contribution rates than those of voluntarily enrolled workers.

\section{Background}

The pension landscape in the United States has been gradually shifting as employers move away from offering their employees defined benefit (DB) pension plans towards offering them DC plans. Between 1989 and 2014, the proportion of private industry, full-time workers participating in DB pension plans declined from 42 to 19 percent, while the share participating in DC plans increased from 40 to 52 percent (Wiatrowski 2011; U.S. Bureau of Labor Statistics 2014). The rise in DC plans has introduced problems not typically experienced with DB pensions, such as voluntary participation. In DB pensions, employees are usually automatically enrolled and typically cannot opt out. Although this is slowly changing, in most DC plans employees must elect to participate. As a result, participation rates among private wage and salary workers in 2014 who were offered an employer retirement plan were 86 percent in DB pensions but only 70 percent in DC plans (U.S. Bureau of Labor Statistics 2014). Even among full-time workers — whose participation rates are typically higher-participation rates were 88 percent in DB pensions but only 74 percent in DC plans (U.S. Bureau of Labor Statistics 2014).

Those employees who are offered plans yet choose not to participate are most concerning to policymakers. ${ }^{1}$ Not only are these workers not taking advantage of tax-deferred opportunities to save for retirement, but many are giving away money by not taking advantage of their employer's matching contributions. Recognizing the capacity for automatic enrollment to increase participation in DC plans and thereby increase retirement savings, the U.S. Treasury Department authorized employers' adoption of auto enrollment in 1998 for new hires and again in 2000 for previously hired employees not already participating in their employer's plan (Choi et al. 2004).

Automatic enrollment (also known as “negative election”) is a 401(k) plan feature in which elective employee deferrals begin without requiring the employee to submit a request to

\footnotetext{
${ }^{1}$ Karamcheva and Sanzenbacher (2010) use the Survey of Income and Program Participation to explore some of the reasons workers do not participate in their employers' defined contribution plans. While opt-out mechanisms are unlikely to increase participation among workers whose reasons for not participating are related to eligibility or monetary constraints, such as "cannot afford to contribute” or "do not want to tie up money," automatic enrollment might be effective when non-participation is due to inertia—for example, "not thinking about it."
} 
join the plan. When automatic enrollment is present, employees have a pre-determined percentage of their pay deferred as soon as they become eligible for the plan. If employees do not want to participate, they must actively request to be excluded from the plan.

Several studies and anecdotal accounts suggest that automatic enrollment has succeeded in dramatically increasing 401(k) participation (Beshears et al. 2010; Choi et al. 2002, 2004; Madrian and Shea 2001). Madrian and Shea (2001), for example, document a 48 percentage point increase in 401(k) participation among newly hired employees and an 11 percentage point increase in participation overall at one large U.S. company 15 months after the adoption of automatic enrollment. The authors also note that automatic enrollment has been particularly successful at increasing 401(k) participation among employees least likely to participate in retirement savings plans, namely those who are young, lower paid, black, or Hispanic. Beshears et al. (2010) find that automatic enrollment raises participation even in the absence of more traditional plan features known to be effective, such as the employer match.

Although participation has been demonstrated to increase with automatic enrollment, studies have also shown that automatically enrolled employees tend to remain with the default options in their plan. Madrian and Shea (2001) show that, at least in the short term, only a small fraction of automatically enrolled 401(k) participants elect a contribution rate or asset allocation that differs from the company-specified default. Moreover, most employers set the default employee contribution in their $401(\mathrm{k})$ plans at a rate that does not take full advantage of the employer match (Butrica and Karamcheva 2012). A Vanguard study finds that automatic enrollment leads to lower plan contribution rates, as participants who would have voluntarily saved at a higher rate remain at the lower default contribution rates (Nessmith, Utkus, and Young 2007).

Empirical findings on the effects of automatic enrollment on participation and contributions, so far, originate from three main sources, each having its disadvantages. One such source, individual firm case studies, observe participants' behavior before and after automatic enrollment but typically do not generalize to the larger population of workers (e.g. Madrian and Shea 2001; Beshears et al. 2010). Proprietary plan-level data from plan sponsors usually cover a substantial number of predominantly larger plans but are not necessarily representative of all covered workers (e.g. Nessmith, Utkus and Young 2007; VanDerhei 2010; Vanguard 2012). Finally, firm-level data such as the Form 5500 series or the National Compensation Survey 
(NCS), while nationally representative, lack important demographic and socioeconomic information necessary to analyze individual participants' behavior (e.g. Soto and Butrica 2009; Butrica and Karamcheva 2012).

This paper reexamines the determinants of DC plan participation and contributions in the presence of automatic enrollment using data that is nationally representative of older workers and also includes detailed information on their characteristics and economic circumstances.

\section{Data}

Our data come from the Health and Retirement Study (HRS), a large nationally representative survey of Americans age 50 and older that has been tracking households since 1992. The HRS provides valuable information on personal characteristics, employment, earnings, income, financial assets, and pensions. In 2006, the HRS began asking household respondents about automatic enrollment, making it the first nationally representative household survey to collect this information. Unfortunately, the skip pattern in the questions involving auto enrollment has changed twice since they were first asked. In 2006, only respondents included in a DC plan were asked about auto enrollment. In 2008 and 2010, these respondents plus respondents who were not included but eligible were asked whether the plan is one where workers are automatically enrolled. Once again in 2012, only respondents included in a DC plan were asked about auto enrollment. So while most of our analyses use pooled data from the 2006, 2008, 2010, and 2012 waves to analyze automatic enrollment for those included in retirement plans, our analyses of respondents offered DC plans are based only on pooled data from the 2008 and 2010 waves.

We define workers as individuals who are working at the interview date and report positive earnings. Workers are offered a DC plan if they report being included in their employer's DC plan or, if not included, they report that their employer offers a DC plan for which they are eligible but choose not to participate. Workers are included in a plan if they report being included in their employer's DC plan and also report that they or their employers contributed (positive amounts) to their accounts. This measure is similar to what is sometimes called participation. For example, in the National Compensation Survey, the Bureau of Labor 
Statistics classifies participants as all those in noncontributory plans plus those in contributory plans who have made the required contributions. ${ }^{2}$

Information on automatic enrollment comes from a couple of questions in the HRS survey. First, workers who are included in a pension plan are asked whether they were given a choice to participate or were enrolled automatically when they became eligible to participate in the company's retirement/pension plan. Second, in 2008 and 2010 the survey added a similar question for workers who are not included in a plan but whose employer offers a plan for which they are eligible. These workers are asked whether their firm requires employees to sign up for this plan or whether they are automatically enrolled.

We look at the main plan when analyzing contribution amounts and rates. Contribution amounts are the contribution rate multiplied by earnings, unless respondents report their contribution amount. Contribution rates are contributions divided by earnings, unless respondents report their contribution rate. We express all dollar amounts in constant 2012 dollars (indexed to changes in the Consumer Price Index).

Our analyses focus on private sector workers. For the descriptive analyses, we restrict the sample to workers ages 55 to 69 in each of the pooled waves to ensure the results are nationally representative and to minimize age bias across waves. For the multivariate analyses, we examine those who are less than age 70 in each of the pooled waves.

\section{Methodology}

We begin our analyses by showing how rates of being included in a DC plan and making positive contributions, as well as how contribution levels and contribution rates differ between automatically enrolled and voluntarily enrolled workers. We also examine the extent to which we observe the same differences by job tenure and earnings level. We define short-tenure workers as those with four years or less of tenure on the main job.

Then in our empirical specifications, we use linear probability models to analyze the likelihood of being including in a DC plan if offered a DC plan and the determinants of making

\footnotetext{
${ }^{2}$ Turner, Muller, and Verma (2003) note that there are many different definitions of pension participation. The three definitions commonly used are based on: positive account balances (regardless of whether the employee or employer made contributions), the worker answering "yes" to the question "Are you a participant," and the worker contributing to a plan.
} 
positive contributions to a DC plan if included in one. ${ }^{3}$ Next, we use ordinary least squares (OLS) regression models to analyze the determinants of contribution rates and contribution levels for those included in a DC plan. ${ }^{4}$

We separately analyze employee, employer, and total contributions as functions of personal demographic and socioeconomic characteristics and the automatic enrollment provision—our main variable of interest. Other predictors in the models include age, sex, education, race, marital status, the logs of non-labor income and of wealth, whether the spouse makes contributions to his or her DC plan, and year dummies to capture changes in worker behavior over time. We also include an indicator of whether the worker is a short-tenure worker on the current job and indicators of earnings quintiles.

\section{Results}

First, we describe how rates of being included in, and making positive contributions to, DC plans differ between automatically and voluntarily enrolled workers. Then we show how contribution levels and rates differ by automatic enrollment. We focus on the degree to which any overall differences we observe are similar by job tenure and earnings level. Finally, we discuss our results from multivariate analyses that control for various demographic and economic characteristics and highlight the extent to which these results support our descriptive findings.

\section{Does Being Included and Contributing to DC Plans Differ by Automatic Enrollment?}

Among older workers offered a DC plan, we find that those with auto enrollment are more likely to be included in a retirement plan than those without auto enrollment. For example, 92.7 percent of older workers who are automatically enrolled are included in a DC plan, compared with only 84.9 percent of those who were given the option to enroll (table 1). Differences by auto enrollment in the share of workers who report being included in a DC plan are largest for short-tenure workers and the lowest earners. For example, among short-tenure workers offered a DC plan, 80.8 percent of those who are auto enrolled report being included in the plan, compared with only 68.2 percent of those who voluntarily enroll. Also, among the lowest earners offered a

\footnotetext{
${ }^{3}$ We prefer linear probability models to probit or logit models because the linear framework makes the interpretation of the marginal effects on the interaction terms easier (interaction terms include automatic enrollment interacted with short-tenure worker status or with earnings quintiles). The results from corresponding probit models are similar and are available upon request.

${ }^{4}$ In all specifications, we report panel-robust standard errors clustered on individual level.
} 
DC plan, 91 percent of those auto enrolled report being included in the plan, compared with only 51.6 percent of those who opt in. So, similar to other studies, we find evidence suggesting that automatic enrollment increases the percentage of workers included in DC plans-particularly those workers least likely to voluntarily opt in.

Different from other studies, however, we also find that among those included in a plan, workers who were automatically enrolled when they became eligible are less likely to contribute to their DC plan than those who voluntarily enrolled (Table 2). This finding could reflect differences in the composition of workers if auto-enrolled workers are less inclined to save than voluntarily enrolled workers. It could also reflect differences in the composition of plans if autoenrolled workers are more likely than opt-in workers to be in noncontributory plans. ${ }^{5}$ Finally, it could reflect confusion among auto-enrolled workers who are unsure whether contributions come from them or their employers, because they were defaulted into contributing to their plans. The HRS does not allow us to separately identify these potential causes; however, it does provide some evidence that the higher presence of noncontributory plans among workers with automatic enrollment plan features might be a significant driver. ${ }^{6}$

According to the HRS, among older workers included in a DC plan, only 65.3 percent of those with auto enrollment report contributing to the plan compared with 95.5 percent of those without auto enrollment. Although differences by auto enrollment in the share of workers included in DC plans are considerably higher for short-tenure workers and lower earners (see Table 1), this is not the case for the share of workers contributing to DC plans among those included in these plans.

\footnotetext{
${ }^{5}$ For our analysis, noncontributory plans are those plans which permit but do not require employees to contribute. This definition would include money-purchase or profit-sharing plans that typically do not require employee contributions, as well as 401(k) plans with noncontingent employer contributions.

${ }^{6}$ Starting with the 2008 wave, respondents were asked to report the name of the plan they are included in ("how the employer calls it”). We grouped the plans in four categories: 401(k), 401(k)-like (supplemental retirement A, 401a, 403b, 457, thrift and savings, SEP or simple plan), profit-sharing or similar (employee stock ownership, money purchase plan, employee stock purchase, stock ownership and purchase), and general DC. Based on pooled data from the 2008, 2010, and 2012 waves, automatic enrollment is significantly more prevalent among profit-sharing plans (48 percent), compared with 401(k) (19 percent) or 401(k)-like (21 percent) plans. Additionally, for autoenrolled workers, the chances of receiving employer contributions do not appear to depend on employees contributing themselves. The share of those receiving employer contributions is about 85 percent both for employees who contribute and those who do not. For voluntarily enrolled workers, in contrast, the chances of receiving employer contributions do appear to depend on whether employees contribute. The share of those receiving employer contributions is 81 percent for employees who contribute, but only 57 percent for employees who do not contribute.
} 
Differences by automatic enrollment are similar for long-tenure and short-tenure workers and reflect the overall differences; however, they are less similar across the earnings distribution. Among the lowest earners, only 59.2 percent of opt-out workers make contributions compared with 90.8 percent of opt-in workers. This gap, roughly 32 percentage points, is similar for workers through the fourth earnings quintile but shrinks slightly for those in the top quintile. Among the highest earners, 70.8 percent of opt-out workers contribute to their plans compared with 97 percent of opt-in workers-a 26-percentage-point difference.

In contrast, we find that auto-enrolled workers are more likely to receive employer contributions to their DC plans than voluntarily enrolled workers (Table 2). Overall, 90.6 percent of workers with automatic enrollment report employer contributions compared with only 86.8 percent of workers without auto enrollment. The largest differences are for long-tenure workers (5 percentage points) and the lowest and highest earners ( 7 percentage points and 8 percentage points, respectively).

Contribution Levels among Workers in DC Plans. Among older workers included in a DC plan, the median employee contribution amount is significantly lower for those who are automatically enrolled than for those who are not-regardless of job tenure and earnings level (Table 3). At least some of this difference is driven by the lower incidence of positive contributions among those automatically enrolled (see Table 2).

The typical worker contributes only \$1,293 per year if auto enrolled and \$3,354 per year if not—with the largest level differences being for long-tenure workers and the highest earners, but the largest percentage differences being for short-tenure workers and for lower earners. For example, auto-enrolled, short-tenure workers contribute \$1,934 (72 percent) less than those who voluntarily enroll. In contrast, auto-enrolled, long-tenure workers contribute \$2,119 (60 percent) less than those who voluntarily enroll. Additionally, the lowest earners with automatic enrollment contribute $\$ 406$ (70 percent) less than those without it. The highest earners with automatic enrollment, in contrast, contribute \$2,984 (34 percent) less than those without it.

The distribution of contribution amounts tells a similar story. Figure 1 includes histograms of employee contribution amounts for workers who reported being automatically enrolled and those who said they were given a choice whether to enroll. They show that 52 
percent of auto-enrolled workers contribute $\$ 1,000$ or less (including nothing) to their retirement plans, compared with only about 21 percent of voluntarily enrolled workers.

Although auto-enrolled workers contribute less to their retirement accounts, their employers contribute more. The typical worker gets $\$ 2,248$ per year in employer contributions if auto enrolled and only \$1,608 per year if not-with the largest level and percentage differences being for long-tenure workers and the highest earners. Figure 2 includes histograms of employer contribution amounts for workers without and with automatic enrollment. They show that 38 percent of auto-enrolled workers receive employer contributions of $\$ 1,000$ or less and 53 percent receive contributions of $\$ 2,000$ or less. In comparison, about 41 percent of voluntarily enrolled workers receive employer contributions of $\$ 1,000$ or less and 61 percent receive contributions of $\$ 2,000$ or less.

To the extent that workers misunderstand where contributions to their plans come from, looking at total contributions might be more appropriate and less prone to measurement bias. When we do this, we find that the higher employer contributions are not high enough to offset the lower employee contributions. The combined effect is that total DC contributions are lower for automatically enrolled workers than for voluntarily enrolled workers-with the level and percentage differences being largest for short-tenure workers. The typical worker has total DC contributions of $\$ 4,800$ per year if auto enrolled and $\$ 6,072$ per year if not. Total contributions for auto-enrolled, short-tenure workers are \$2,291 (46 percent) less than those for opt-in, shorttenure workers. In contrast, total contributions for auto-enrolled, long-tenure workers are only \$784 (12 percent) less than those for opt-in, long-tenure workers. Total contributions by automatic enrollment do not differ (or only slightly differ) in a statistically significant way across the earnings distribution.

Figure 3 includes histograms of total contribution amounts for workers without and with automatic enrollment. They show that about 18 percent of auto-enrolled workers have $\$ 1,000$ or less contributed to their DC plans, compared with only about 10 percent of opt-in workers.

Contribution Rates among Workers in DC Plans. Analyzing contribution amounts can be a bit confusing since they are a function of both earnings and the contribution rate. Next, we examine contribution rates, or the percentage of earnings contributed to the plan, by automatic enrollment. Among older workers included in DC plans, median employee contribution rates are 
significantly lower for workers who are automatically enrolled than for those who are not, regardless of job tenure or earnings (Table 4). As mentioned previously, at least some of this difference is driven by the lower incidence of positive contributions among those automatically enrolled (see Table 2). ${ }^{7}$

The typical worker contributes only 3 percent if auto enrolled and 6 percent if not-with the largest level and percentage differences being for short-tenure workers and the lowest earners. The distribution of contribution rates tells the same story. Figure 4 includes histograms of employee contribution rates for workers with and without auto enrollment. They show that about 45 percent of auto-enrolled workers contribute 2 percent or less (including nothing) to their retirement plans, compared with only 13 percent of workers without auto enrollment.

As with employer contribution amounts, employer contribution rates are higher for workers who are auto enrolled than for those who voluntarily enroll. Overall for the typical worker, employers contribute 4.4 percent if automatically enrolled and only 3 percent if not. The largest and only statistically significant differences are for long-tenure workers and the highest earners. Employers of these workers contribute 5 percent if automatically enrolled and only 3 percent if not. Figure 5 includes histograms of employer contribution rates for workers with and without auto enrollment. They show that employer contribution rates are higher than 4 percent for about 47 percent of auto-enrolled workers, but only 41 percent of voluntarily enrolled workers. Furthermore, employer contribution rates are higher than 8 percent for about 23 percent of workers who are auto enrolled, but only 13 percent of those who were given a choice to enroll.

Taking account of both employee and employer contributions, median total contribution rates are virtually identical for workers who are auto enrolled and those who are not (10 versus 11 percent). In fact, we find no statistically significant differences in median total contribution rates for workers with and without auto enrollment. While this is true for the median values, it does not imply that the distribution of total contribution rates is identical for those with and without automatic enrollment. In fact, Figure 6 shows that the distribution of total contribution rates is skewed more toward lower contribution rates for automatically enrolled workers and skewed more toward higher contribution rates for voluntarily enrolled workers. There is a higher

\footnotetext{
${ }^{7}$ We find that the difference persists, even if diminished, when we restrict the analysis to only those with positive contributions. The results are not reported but are available upon request.
} 
density of workers whose contribution rates are 4 percent or less among those with automatic enrollment than those without. This result is not necessarily surprising since other studies have found that automatically enrolled workers tend to be defaulted into lower-than-average contribution rates and to remain there (Madrian and Shea, 2011; Nessmith, Utkus, and Young 2007). Based on our analysis of older workers in the HRS, however, this result appears to be driven by the propensity for automatically enrolled workers to not contribute to their DC plans.

Multivariate Analyses of the Likelihood of Being Included and Contributing to DC Plans. The descriptive analyses revealed important differences by automatic enrollment with respect to the share of workers included and the share of workers contributing to their employer's DC plan. In this section, we examine whether these relationships still exist after controlling for other factors.

Table 5 presents estimated marginal effects of the independent variables on the probability of being included in an offered DC plan. As previously mentioned, this analysis is limited to only the 2008 and 2010 HRS waves, because these are the only survey years between 2006 and 2012 in which we can infer DC offers for those respondents who report not being included in a DC plan.

The estimates show that the probability of being included if offered a DC plan is higher for workers who are between ages 50 and 59 (compared with those under age 50), have higher wealth, have a spouse who contributes to a DC plan, or have higher earnings than for their counterparts. In contrast, short-tenure workers are less likely than long-tenure workers to be included in a DC plan. For example, short-tenure workers are, on average, 17.4 percentage points less likely to be included in a DC plan than long-tenure workers (column 1). This may reflect waiting periods for new workers or failure to initially enroll in offered plans with new employers. This finding is consistent with other studies (Butrica and Smith, forthcoming; Smith, Johnson, and Muller 2004). Additionally, workers in the bottom quintile of the earnings distribution are 16.3 percentage points and those in the second quintile are 9.6 percentage points less likely to be included compared with those in the middle of the distribution (column 1). Workers in the top quintile, however, are 10.6 percentage points more likely to be included in a DC plan than those in the middle quintile. Automatic enrollment, our key variable of interest, is 
associated with a 10.6 percentage point higher probability of being included in a DC plan and is statistically significant with a 99 percent confidence level.

Columns 2 and 3 display tests for differences in automatic enrollment by job tenure and earnings. As in the descriptive analyses, we find that automatic enrollment has the biggest effect on short-tenure workers and the lowest earners. Automatic enrollment is associated with only a 7.9 percentage point higher likelihood of being included in a DC plan for long-tenure workers but a 20.3 percentage point higher likelihood of being included for short-tenure workers (column 2). ${ }^{8}$ Additionally, automatic enrollment's positive effect on being included in a DC plan declines with earnings. For example, auto enrollment is correlated with a 29.3 percentage point increase in the likelihood of being included in a plan for the lowest earners, a 14.1 percentage point increase in the likelihood for middle earners, and only a 4.1 percentage point increase in the likelihood for the highest earners (column 3).

Table 6 presents estimated marginal effects of the independent variables on the probability of contributing to a DC plan among those included. In this analysis, we estimate separate regressions for employee and employer contributions. The likelihood that a worker contributes to a DC plan is positively correlated with being a higher earner. Workers in the bottom quintile of the earnings distribution are 6.1 percentage points less likely to contribute to their DC plans than those in the middle of the distribution (column 1). Workers in the top quintile, however, are 4.4 percentage points more likely to contribute to their DC plans than those in the middle quintile. Finally, we find that workers who are automatically enrolled are 32.3 percentage points less likely to contribute to their plans than those who opt in. The result is similar in magnitude to the one in the descriptive analysis (see Table 2), and, as mentioned before, is likely driven by a number of possible factors. Auto-enrolled workers might be less inclined than opt-in workers to save. Alternatively, auto-enrolled workers might be less likely than opt-in workers to be in plans that require them to contribute. Finally, auto-enrolled workers might be confused about whether contributions come from them or their employers, because they were defaulted into contributing to their plans. Unfortunately, we are not able to disentangle these causes with the data available.

\footnotetext{
${ }^{8}$ This finding is based on a T-test on the sum of the coefficient on automatic enrollment and the coefficient on the interaction term between automatic enrollment and short-tenure worker status. We test whether that linear combination is significantly different from zero. We use the same procedure to test for the effect of automatic enrollment on individuals in different earnings quintiles.
} 
Table 6 also shows evidence of heterogeneous effects of automatic enrollment by job tenure and earnings. In particular, auto enrollment seems to have less of a negative effect on the likelihood of contributing to a DC plan for short-tenure workers and the highest earners. While long-tenure workers are 33.9 percentage points less likely to contribute to a DC plan if auto enrolled than if voluntarily enrolled, short-tenure workers are only 25.5 percentage points less likely to contribute if automatically enrolled (column 2). Among the lowest earners, those who are auto enrolled are 32.2 percentage points less likely to contribute to their plans than those who opt in (column 3). Among the highest earners, those who are auto enrolled are 30.6 percentage points less likely to contribute to their plans than those who voluntarily enroll.

Although auto-enrolled workers are less likely to contribute to their DC plans, they are more likely than opt-in workers to be in plans that their employers contribute to. For example, auto-enrolled workers are 2.9 percentage points more likely than opt-in workers to have employers contribute to their DC plans (column 4). Similar to the descriptive results and even controlling for other factors, automatic enrollment has a larger effect on long-tenure workers and the highest earners. If employees are automatically enrolled, the possibility of receiving employer contributions increases 3 percentage points for long-tenure workers (column 5) and 5.4 percentage points for the highest earners (column 6). However, automatic enrollment has no statistically significant effect on short-tenure workers or the lowest earners.

Multivariate Analyses of Contribution Amounts and Contribution Rates. The descriptive analyses revealed important differences in DC contributions by automatic enrollment. In this section, we examine whether these relationships still exist after controlling for other factors.

Table 7 shows results from OLS models of contribution amounts among workers included in a DC plan. As expected, employee contribution amounts are positively associated with having a college degree, higher other income, and higher wealth. Additionally, both employee and employer contributions increase with workers' earnings.

With respect to automatic enrollment, we find that auto-enrolled workers contribute $\$ 1,684$ less per year to their DC plans than opt-in workers (column 1). Linear combination tests suggest that automatic enrollment affects employee contribution amounts differently by job tenure and earnings level—with the largest differences being for long-tenure workers and the highest earners. For example, long-tenure workers contribute about \$1,845 less and short-tenure 
workers contribute $\$ 1,021$ less if they are auto enrolled than if they opt in (column 2).

Additionally, automatic enrollment's negative correlation with employee contributions increases with earnings. For example, the lowest earners contribute \$462 less, middle earners contribute \$913 less, and the highest earners contribute \$3,161 less if they are automatically enrolled than if they voluntarily enroll (column 3).

Although automatic enrollment is correlated with lower employee contributions, it is also associated with higher employer contributions, particularly among high earners (columns 4-6). On the surface, this finding appears to contradict the finding reported in Butrica and Karamcheva (2012), which found that employer match rates were lower among plans with auto enrollment than those without. However, that finding was based on plans, considered only contributory plans (i.e. plans with employer matches), and it analyzed plan match generosity among plans with flat match structures rather than actual employer contribution rates, which are a function of both plan match generosity and employee behavior. In contrast, the current finding is based on workers, potentially considers both noncontributory and contributory plans, and analyzes actual contributions rather than match generosity. We find that annual employer contributions are \$2,158 higher for the top earners who auto enroll than for those who do not. However, we find no statistically significant differences by automatic enrollment for those who are not the top earners.

The combined effect of lower employee contributions and higher employer contributions is that older workers who report being automatically enrolled deposit around $\$ 900$ less (employee plus employer contributions) per year into their DC accounts than those who voluntarily enroll (column 7). However, there are no statistically significant differences in this correlation by job tenure or earnings level (columns 8-9).

Finally, Table 8 presents findings from OLS regressions of contribution rates. Higher education, other income, wealth, and earnings are all associated with higher employee contribution rates. Automatic enrollment, in contrast, is associated with lower employee contribution rates-a finding that also confirms the descriptive results. Employee contribution rates are 2.6 percentage points lower for automatically enrolled workers than for opt-in workers (column 1). Linear combination tests suggest that the negative correlation between automatic enrollment and employee contribution rates is slightly larger for long-tenure workers than shorttenure workers (-2.7 percentage points versus -2 percentage points in column 2$)$, but roughly 
constant across earnings quintiles (-2.7 for the lowest earners, -2.4 for those in the middle, and 2.8 for the highest earners in column 3).

Automatic enrollment is also associated with higher employer contribution rates.

Overall, employer contribution rates are 1.1 percentage points higher for auto-enrolled workers than for voluntarily enrolled workers (column 4). The largest differences are for long-tenure workers and the highest earners. Among long-tenure workers, for example, those who are auto enrolled have employer contribution rates that are 1.2 percentage points higher than those who are voluntarily enrolled (column 5). In contrast, auto enrollment has no statistically significant difference on the employer contribution rates of short-tenure workers. Additionally, automatic enrollment is associated with employer contribution rates that are 2.1 percentage points higher for the highest earners, but only 1.1 percentage points higher for workers in the second earnings quintile, and insignificant for the lowest and middle earners (column 6).

The combined effect is that total contribution rates are 1.6 percentage points lower for auto-enrolled workers compared with voluntarily enrolled workers (column 7). Among longtenure workers, automatic enrollment is associated with total contribution rates that are 1.8 percentage points lower; however, there is no statistically significant difference for short-tenure workers (column 8). Automatic enrollment is associated with lower total contribution rates for workers in the middle of the earnings distribution but not for those at the bottom or the top of earnings.

\section{Discussion}

Demographic trends and impending reforms suggest that Social Security will likely replace a smaller share of pre-retirement earnings than it does today, increasing the importance of employer-sponsored retirement plans in providing adequate income. Although "auto-pilot" features in 401(k) plans have been linked to increased participation rates, relatively little is known about how such plan features may affect the distribution of tax-deferred contributions on a national scale. This paper aims to fill some of that gap in the literature and to inform the policy debate on the evolution of retirement income security. We analyze the relationship between automatic enrollment and DC contributions using data from the first nationally representative survey that asks respondents about auto enrollment. The results suggest that the relationship 
between automatic enrollment and DC contributions may be more ambiguous than policymakers expect.

Consistent with other studies, the results show that automatic enrollment is associated with a higher proportion of older workers included in DC plans-particularly short-tenure workers and the lowest earners. Something not highlighted in other studies, however, is the relationship between automatic enrollment and total DC contributions. Controlling for a number of different factors, we find that automatic enrollment is associated with a lower likelihood that older workers will contribute to their DC plans. As a result, employee contribution amounts and contribution rates are, on average, lower among those who report having been automatically enrolled compared with those who were given a choice to enroll. However, we also find that automatic enrollment is associated with an increased probability that older workers' employers will contribute to their plans. As a result, employer contribution amounts and contribution rates are on average higher among auto-enrolled workers than voluntarily enrolled workers.

There could be a number of different drivers behind these results. Workers who are automatically enroll might be less inclined to save than those who opt in. Alternatively, autoenrolled workers might be more likely than voluntarily enrolled workers to be in noncontributory plans, particularly if the Pension Protection Act of 2006 (PPA) is successful in encouraging employers to institute automatic enrollment and those employers are more likely to opt for providing nonelective contributions to avoid nondiscrimination tests. ${ }^{9}$ Not only would this explain the higher incidence and higher magnitude of employer contributions for automatically enrolled workers, it would also explain the lower incidence and lower magnitude of employee contributions. Workers in noncontributory plans do not have to contribute in order to participate in the plan, and they might be less inclined to contribute because their employers do (substitutability between employee and employer contributions). Finally, compared with workers who opt in and make a conscious decision to participate, automatically enrolled workers might be less aware of where contributions to their plans come from and may misclassify an employee default contribution as being made by the employer. The HRS does not allow us to fully disentangle these potential effects, but it does provide evidence that supports differences in the composition of plans between auto-enrolled and voluntarily enrolled workers.

\footnotetext{
${ }^{9}$ Safe harbor rules allow employers to avoid nondiscrimination tests if they match employees' contributions (up to 4 percent of pay under the 401(k) safe harbor or 3.5 percent of pay under the PPA automatic enrollment safe harbor) or provide a nonelective contribution of at least 3 percent of compensation for all eligible employees.
} 
In any case, our results show that the higher employer contributions associated with automatic enrollment are not high enough to offset the lower employee contributions. The combined effect is that the retirement accounts of automatically enrolled older workers receive, on average, \$900 less in annual total contributions and their contribution rates are 1.6 percentage points lower than those of voluntarily enrolled workers.

Overall, our findings based on the HRS data suggest that while automatic enrollment is effective at expanding enrollment of older workers in DC plans, it could do a better job of both increasing the share of workers who contribute and boosting overall contribution levels. Nevertheless, there are two important caveats to keep in mind. First, because this analysis focuses on older workers, our results may not generalize to all workers. Second, because the HRS does not include much information on retirement plan provisions, we can only hypothesize possible explanations for our results. The PPA included several features designed to enhance DC plans, which also increased employers' choice of plan provisions. Features such as new protections for automatic enrollment (through preempting state payroll-withholding laws and expanding employer fiduciary protections) and more advantageous nondiscrimination safe harbor rules for employers who adopt automatic enrollment might lead to significant shifts in the composition of DC plans. Consequently, employer decisions regarding retirement provisions will likely play an increasingly larger role in employee savings behavior and ultimately their retirement account balances. 


\section{References}

Bassett, William F., Michael J. Fleming, and Anthony P. Rodrigues. 1998. "How Workers Use 401(k) Plans: The Participation, Contribution, and Withdrawal Decisions. National Tax Journal 51(23): 263-89.

Beshears, John, James J. Choi, David Laibson, and Brigitte C. Madrian. 2010. "The Impact of Employer Matching on Savings Plan Participation under Automatic Enrollment.” Research Findings in the Economics of Aging, edited by David A. Wise (311-327). Chicago, IL: University of Chicago Press.

Butrica, Barbara A. and Nadia S. Karamcheva. 2012. “Automatic Enrollment, Employee Compensation, and Retirement Security.” Retirement Policy Discussion Paper No. 12-02. Washington, DC: Urban Institute.

Butrica, Barbara A. and Karen E. Smith. 2015 (forthcoming). “401(k) Participant Behavior in a Volatile Economy.” Journal of Pension Economics and Finance.

Choi, James J., David Laibson, Brigitte C. Madrian, and Andrew Metrick. 2002. "Defined Contribution Pensions: Plan Rules, Participant Decisions, and the Path of Least Resistance." Tax Policy and the Economy Volume 16, edited by James Poterba (67-114). Cambridge, MA: MIT Press.

Choi, James J., David Laibson, Brigitte C. Madrian, and Andrew Metrick. 2004. "For Better or For Worse: Default Effects and 401(k) Savings Behavior.” In Perspectives in the Economic of Aging, edited by David A. Wise (81-121). Chicago, IL: University of Chicago Press.

Dushi, Irena, Howard M. Iams, and Christopher R. Tamborini. 2011. "Defined Contribution Pension Participation and Contributions by Earnings Levels Using Administrative Data.” Social Security Bulletin 71(2): 67-76.

Dworak-Fisher, Keenan. 2011. “Matching Matters in 401(k) Plan Participation.” Industrial Relations 50(4): 713-737.

Karamcheva, Nadia S. and Geoffrey Sanzenbacher. 2010. "Is Pension Inequality Growing?” Issues in Brief 10-1. Chestnut Hill, MA: Center for Retirement Research at Boston College.

Madrian, Brigitte C. and Dennis F. Shea. 2001. "The Power of Suggestion: Inertia in 401(K) Participation and Savings Behavior.” The Quarterly Journal of Economics 116(4):1149-87.

Nessmith, William E., Stephen P. Utkus, and Jean A. Young. 2007. “Measuring the Effectiveness of Automatic Enrollment.” Volume 31. Valley Forge, PA: Vanguard Center for Retirement Research. 
Soto, Maurico and Barbara A. Butrica. 2009. "Will Automatic Enrollment Reduce Employer Contributions to 401(k) Plans?” Washington, DC: Urban Institute.

Smith, Karen E, Richard W. Johnson, and Leslie Muller. 2004. "Deferring Income in EmployerSponsored Retirement Plans: The Dynamics of Participant Contributions.” National Tax Journal 57(3): 639-670.

Turner John, Leslie Muller, and Satyendra K. Verma. 2003. "Defining Participation in Defined Contribution Plans." Monthly Labor Review. August.

U.S. Bureau of Labor Statistics. 2014. National Compensation Survey: Employee Benefits in the United States, March 2014. Washington, DC: U.S. Department of Labor.

Vanguard. 2006/2012. "How America Saves: A Report on Vanguard Defined Contribution Plan Data.” Valley Forge, PA: Vanguard Institutional Investor Group.

VanDerhei, Jack. 2010. “The Impact of Automatic Enrollment in 401(k) Plans on Future Retirement Accumulations: A Simulation Study Based on Plan Design Modifications of Large Plan Sponsors.” Issue Brief No. 341. Washington, DC: Employee Benefit Research Institute.

Wiatrowski, William J. 2011. Changing Landscape of Employer-Based Retirement Benefits. Washington, DC: U.S. Bureau of Labor Statistics. 
Table 1. Share of Workers Ages 55 to 69 Included in a DC Plan among Those Offered a Plan, by Auto-enrollment Status (\%)

\begin{tabular}{lccc}
\hline & $\begin{array}{c}\text { Auto } \\
\text { enrolled }\end{array}$ & $\begin{array}{c}\text { Voluntarily } \\
\text { enrolled }\end{array}$ \\
\hline Overall & 92.7 & 84.9 & $* * *$ \\
& & & \\
Job tenure & 95.3 & 90.5 & $* * *$ \\
Long-tenure worker & 80.8 & 68.2 & $* * *$ \\
Short-tenure worker & & & \\
& & & \\
Earnings quintile & 91.0 & 51.6 & $* * *$ \\
Bottom & 84.9 & 71.8 & $* *$ \\
Second & 88.1 & 79.1 & $* *$ \\
Third & 92.4 & 90.5 & $*$ \\
Fourth & 97.4 & 96.1 & $*$ \\
Top & & & \\
\end{tabular}

Notes: Sample includes workers ages 55 to 69 who are not self-employed and who report positive wages.

Respondents are included in a plan if they report being included and they or their employer contributes to their DC plan. Significance: $* * * \mathrm{p}<0.01, * * \mathrm{p}<0.05, * \mathrm{p}<0.1$

Source: Authors' calculations from the 2008 and 2010 waves of the Health and Retirement Study. 
Table 2. Share of Workers Ages 55 to 69 Who Contribute or Whose Employer Contributes to Their DC Plan among Those Included in a Plan, by Auto-enrollment Status (\%)

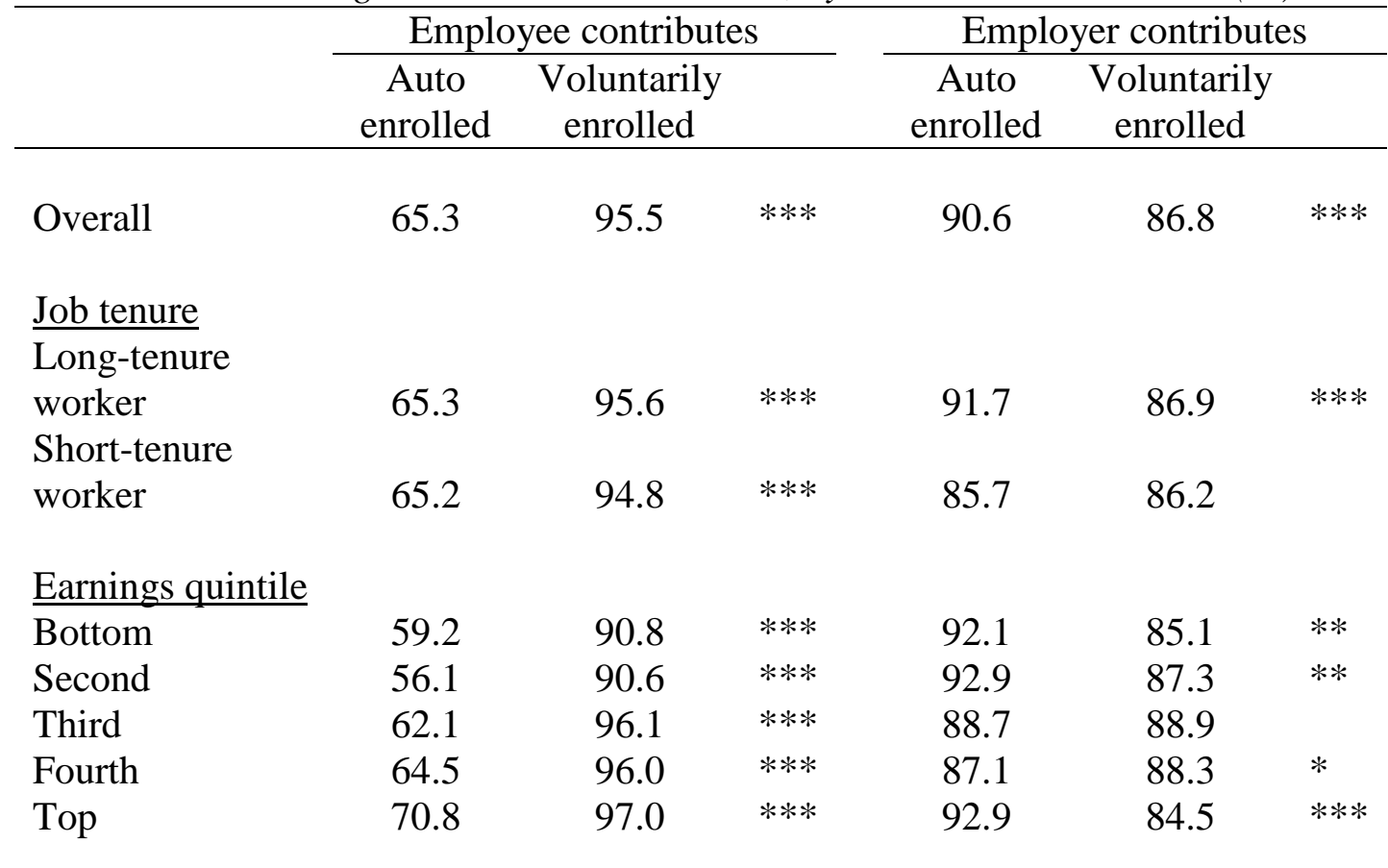

Notes: Sample includes workers ages 55 to 69 who are not self-employed and who report positive wages. Respondents are included in a plan if they report being included and they or their employer contributes to their DC plan. Significance: ${ }^{* * *} \mathrm{p}<0.01,{ }^{* *} \mathrm{p}<0.05,{ }^{*} \mathrm{p}<0.1$.

Source: Authors' calculations from the 2006-2012 waves of the Health and Retirement Study. 
Table 3. Median Contribution Amounts among Workers Ages 55 to 69 Included in a DC Plan, by Auto-enrollment Status (2012 dollars)

\begin{tabular}{|c|c|c|c|c|c|c|c|c|c|}
\hline & \multicolumn{3}{|c|}{ Employee contributions } & \multicolumn{3}{|c|}{ Employer contributions } & \multicolumn{3}{|c|}{ Total contributions } \\
\hline & $\begin{array}{c}\text { Auto } \\
\text { enrolled }\end{array}$ & $\begin{array}{c}\begin{array}{c}\text { Voluntarily } \\
\text { enrolled }\end{array} \\
\end{array}$ & & $\begin{array}{c}\text { Auto } \\
\text { enrolled }\end{array}$ & $\begin{array}{c}\begin{array}{c}\text { Voluntarily } \\
\text { enrolled }\end{array} \\
\end{array}$ & & $\begin{array}{c}\text { Auto } \\
\text { enrolled }\end{array}$ & $\begin{array}{c}\text { Voluntarily } \\
\text { enrolled }\end{array}$ & \\
\hline Overall & 1,293 & 3,354 & $* * *$ & 2,248 & 1,608 & $* * *$ & 4,800 & 6,072 & ** \\
\hline Job tenure & & & & & & & & & \\
\hline $\begin{array}{l}\text { Long-tenure } \\
\text { worker } \\
\text { Short-tenure }\end{array}$ & 1,396 & 3,515 & $* * *$ & 2,540 & 1,726 & $* * *$ & 5,696 & 6,480 & ** \\
\hline $\begin{array}{l}\text { snort-tenure } \\
\text { worker }\end{array}$ & 751 & 2,685 & $* * *$ & 1,700 & 1,398 & & 2,743 & 5,034 & ** \\
\hline Earnings quin & & & & & & & & & \\
\hline Bottom & 171 & 577 & $* * *$ & 521 & 450 & & 973 & 1,065 & \\
\hline Second & 459 & 1,069 & $* * *$ & 940 & 740 & & 1,754 & 2,009 & * \\
\hline Third & 737 & 1,903 & $* * *$ & 1,080 & 1,119 & & 2,997 & 3,330 & * \\
\hline Fourth & 1,591 & 3,355 & $* * *$ & 2,007 & 1,691 & & 5,131 & 5,760 & * \\
\hline Top & 5,716 & 8,700 & $* * *$ & 5,187 & 3,366 & $* * *$ & 12,350 & 13,156 & \\
\hline
\end{tabular}

Notes: Sample includes workers ages 55 to 69 who are not self-employed and who report positive wages.

Respondents are included in a plan if they report being included and they or their employer contributes to their DC plan. Significance: ${ }^{* * *} \mathrm{p}<0.01,{ }^{* *} \mathrm{p}<0.05,{ }^{*} \mathrm{p}<0.1$.

Source: Authors' calculations from the 2006-2012 waves of the Health and Retirement Study. 
Table 4. Median Contribution Rates among Workers Ages 55 to 69 Included in a DC Plan, by Auto-enrollment Status (\%)

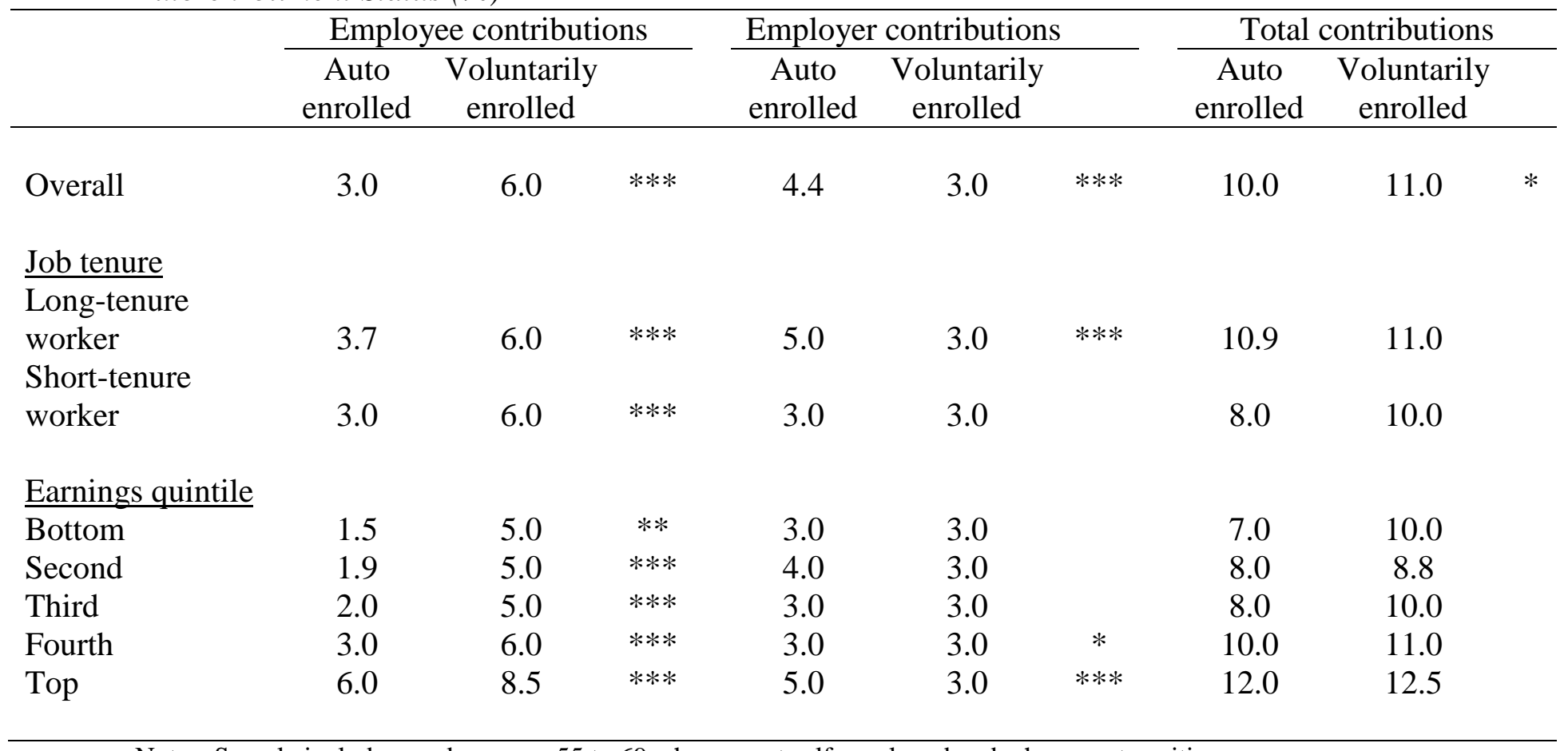

Notes: Sample includes workers ages 55 to 69 who are not self-employed and who report positive wages.

Respondents are included in a plan if they report being included and they or their employer contributes to their DC plan. Significance: $* * * \mathrm{p}<0.01,{ }^{*} \mathrm{p}<0.05$, $* \mathrm{p}<0.1$.

Source: Authors' calculations from the 2006-2012 waves of the Health and Retirement Study. 
Table 5. Linear Probability Model of Being Included in a DC Plan if Offered among Workers under Age 70

\begin{tabular}{|c|c|c|c|}
\hline \multirow[b]{2}{*}{ Variable } & \multicolumn{3}{|c|}{$\begin{array}{l}\operatorname{Pr}(\text { included in DC plan=1|offered DC } \\
\text { plan=1) }\end{array}$} \\
\hline & $(1)$ & (2) & (3) \\
\hline \multicolumn{4}{|l|}{ [omitted group: <50] } \\
\hline Age 50-59 & $0.048 *$ & $0.049 *$ & $0.050 *$ \\
\hline Age 60-69 & -0.007 & -0.005 & -0.004 \\
\hline Male & $-0.038 * * *$ & $-0.038 * * *$ & $-0.038 * * *$ \\
\hline High school graduate & -0.011 & -0.011 & -0.005 \\
\hline Some college & -0.019 & -0.018 & -0.014 \\
\hline College & -0.014 & -0.014 & -0.013 \\
\hline Black & -0.007 & -0.006 & -0.005 \\
\hline Other & 0.018 & 0.017 & 0.020 \\
\hline In a coupled household & 0.011 & 0.012 & 0.013 \\
\hline Log other income & 0.002 & 0.002 & 0.002 \\
\hline Log wealth & $0.012 * * *$ & $0.012^{* * *}$ & $0.012 * * *$ \\
\hline Spouse contributes to DC & $0.048 * * *$ & $0.048 * * *$ & $0.049 * * *$ \\
\hline Short-tenure (tenure <=4 years) & $-0.174 * * *$ & $-0.200 * * *$ & $-0.174 * * *$ \\
\hline Bottom earnings quintile & $-0.163 * * *$ & $-0.163 * * *$ & $-0.198 * * *$ \\
\hline 2nd earnings quintile & $-0.096 * * *$ & $-0.097 * * *$ & $-0.105^{* * *}$ \\
\hline 4th earnings quintile & $0.073 * * *$ & $0.072 * * *$ & $0.095 * * *$ \\
\hline Top earnings quintile & $0.106^{* * *}$ & $0.107 * * *$ & $0.134 * * *$ \\
\hline Year 2008 & $0.035 * * *$ & $0.037 * * *$ & $0.035 * * *$ \\
\hline Automatic enrollment & $0.106 * * *$ & $0.079 * * *$ & $0.141 * * *$ \\
\hline Automatic enrollment * Short-tenure & & $0.124 * * *$ & \\
\hline Automatic enrollment $*$ Bottom quintile & & & $0.152 * *$ \\
\hline Automatic enrollment * 2nd quintile & & & 0.051 \\
\hline Automatic enrollment $* 4$ th quintile & & & $-0.091 * *$ \\
\hline Automatic enrollment $*$ Top quintile & & & $-0.100 * * *$ \\
\hline Pseudo $\mathrm{R}^{2}$ & 0.1852 & 0.1857 & 0.1855 \\
\hline Number of observations & 3,398 & 3,398 & 3,398 \\
\hline
\end{tabular}

Notes: Sample includes workers under age 70 who are not self-employed and who report positive wages.

Respondents are included in a plan if they report being included and they or their employer contributes to their DC plan. Significance: $* * * \mathrm{p}<0.01,{ }^{* *} \mathrm{p}<0.05,{ }^{*} \mathrm{p}<0.1$.

Source: Authors' calculations from the 2006-2012 waves of the Health and Retirement Study. 
Table 6. Linear Probability Model of Contributing to a DC Plan among Workers under Age 70 Included in a Plan

Pr(contribute to DC plan=1|included in DC plan=1)

\begin{tabular}{|c|c|c|c|c|c|c|}
\hline \multirow[b]{3}{*}{ Variable } & \multicolumn{6}{|c|}{$\operatorname{Pr}($ contribute to DC plan=1|included in DC plan=1) } \\
\hline & \multicolumn{3}{|c|}{ Employee contributes } & \multicolumn{3}{|c|}{ Employer contributes } \\
\hline & $\overline{(1)}$ & $(2)$ & (3) & (4) & (5) & (6) \\
\hline \multicolumn{7}{|l|}{ [omitted group: <50] } \\
\hline Age 50-59 & 0.019 & 0.021 & 0.019 & -0.002 & -0.002 & -0.002 \\
\hline Age 60-69 & 0.006 & 0.008 & 0.006 & 0.004 & 0.004 & 0.003 \\
\hline Male & -0.005 & -0.005 & -0.004 & 0.006 & 0.006 & 0.006 \\
\hline High school graduate & 0.019 & 0.018 & 0.019 & -0.020 & -0.020 & -0.019 \\
\hline Some college & 0.018 & 0.017 & 0.018 & -0.011 & -0.011 & -0.010 \\
\hline College & 0.025 & 0.025 & 0.025 & -0.027 & -0.027 & -0.027 \\
\hline Black & 0.014 & 0.014 & 0.014 & -0.006 & -0.006 & -0.006 \\
\hline Other & 0.017 & 0.015 & 0.017 & -0.004 & -0.004 & -0.006 \\
\hline In a coupled household & -0.014 & -0.012 & -0.014 & -0.009 & -0.009 & -0.009 \\
\hline Log other income & 0.002 & 0.002 & 0.002 & -0.002 & -0.002 & -0.002 \\
\hline Log wealth & 0.001 & 0.000 & 0.001 & 0.000 & 0.000 & 0.000 \\
\hline Spouse contributes to DC & 0.021 & 0.020 & 0.021 & 0.007 & 0.007 & 0.007 \\
\hline Short-tenure (tenure $<=4$ years) & $0.021^{*}$ & 0.001 & $0.021^{*}$ & 0.000 & 0.002 & -0.001 \\
\hline Bottom earnings quintile & $-0.061 * *$ & $-0.061^{* *}$ & $-0.063 * *$ & $-0.093 * * *$ & $-0.093 * * *$ & $-0.069 * *$ \\
\hline 2nd earnings quintile & -0.026 & -0.027 & $-0.028^{*}$ & 0.019 & 0.019 & 0.010 \\
\hline 4th earnings quintile & 0.011 & 0.011 & 0.012 & -0.005 & -0.005 & 0.007 \\
\hline Top earnings quintile & $0.044 * * *$ & $0.044 * * *$ & $0.038 * * *$ & -0.000 & -0.000 & -0.005 \\
\hline Year 2008 & 0.016 & 0.016 & 0.016 & $-0.024 * *$ & $-0.024 * *$ & $-0.024 * *$ \\
\hline Year 2010 & $0.021 *$ & 0.020 & $0.021 *$ & $-0.076 * * *$ & $-0.076 * * *$ & $-0.076 * * *$ \\
\hline Year 2012 & 0.008 & 0.007 & 0.009 & $-0.115^{* * *}$ & $-0.115^{* * *}$ & $-0.116^{* * *}$ \\
\hline Automatic enrollment & $-0.323 * * *$ & $-0.339 * * *$ & $-0.331 * * *$ & $0.029 * *$ & $0.030 * *$ & 0.035 \\
\hline Automatic enrollment * Short-tenure & & $0.084 * *$ & & & -0.006 & \\
\hline Automatic enrollment * Bottom quintile & & & 0.009 & & & -0.084 \\
\hline Automatic enrollment * 2nd quintile & & & 0.006 & & & 0.040 \\
\hline Automatic enrollment * 4th quintile & & & -0.005 & & & -0.050 \\
\hline Automatic enrollment * Top quintile & & & 0.025 & & & 0.019 \\
\hline
\end{tabular}

\begin{tabular}{lcccccc}
\hline Pseudo $\mathrm{R}^{2}$ & 0.1445 & 0.1447 & 0.1452 & 0.0444 & 0.0452 & 0.0474 \\
Number of observations & 5,453 & 5,453 & 5,453 & 5,330 & 5,330 & 5,330 \\
\hline
\end{tabular}

Notes: Sample includes workers under age 70 who are not self-employed and who report positive wages.

Respondents are included in a plan if they report being included and they or their employer contributes to their DC plan. Significance: $* * * \mathrm{p}<0.01, * * \mathrm{p}<0.05, * \mathrm{p}<0.1$.

Source: Authors' calculations from the 2006-2012 waves of the Health and Retirement Study. 
Table 7. OLS Regression of Contribution Amounts among Workers under Age 70 Included in a DC plan

\begin{tabular}{|c|c|c|c|c|c|c|c|c|c|}
\hline \multirow[b]{2}{*}{ Variable } & \multicolumn{3}{|c|}{ Employee contribution } & \multicolumn{3}{|c|}{ Employer contribution } & \multicolumn{3}{|c|}{ Total contribution } \\
\hline & (1) & $(2)$ & (3) & (4) & $(5)$ & (6) & (7) & $(8)$ & (9) \\
\hline \multicolumn{10}{|l|}{ [omitted group: <50] } \\
\hline Age $50-59$ & $1321.5^{* * *}$ & $1344.3^{* * *}$ & $1348.6^{* * *}$ & 398.6 & 394.0 & 362.7 & $1745.7^{* * *}$ & $1783.6^{* * *}$ & $1750.4^{* * *}$ \\
\hline Age 60-69 & $989.2 * * *$ & $1010.7^{* * *}$ & $1027.0 * * *$ & -62.0 & -66.7 & -117.2 & $902.2^{* *}$ & $939.1 * *$ & $908.9 * *$ \\
\hline Male & $545.5 * * *$ & $546.6^{* * *}$ & $517.7 * * *$ & $321.8 * *$ & $321.8 * *$ & $343.3 * *$ & $873.0 * * *$ & $872.8 * * *$ & $868.0 * * *$ \\
\hline High school graduate & 91.2 & 79.5 & 133.8 & -16.3 & -14.0 & -40.8 & 157.3 & 137.5 & 169.1 \\
\hline Some college & -17.1 & -26.6 & 33.9 & 208.1 & 210.0 & 173.0 & 215.8 & 197.3 & 225.5 \\
\hline College & $1199.9 * * *$ & $1192.3^{* * *}$ & $1244.2^{* * *}$ & $692.9 * * *$ & $694.9 * * *$ & $659.9 * *$ & $1887.3^{* * *}$ & $1870.2^{* * *}$ & $1893.4^{* * *}$ \\
\hline Black & -124.4 & -126.0 & -112.9 & 348.3 & 348.4 & 324.5 & 174.5 & 172.3 & 181.4 \\
\hline Other & -34.4 & -57.0 & -0.4 & 386.7 & 390.4 & 361.6 & 439.8 & 410.0 & 442.8 \\
\hline In a coupled household & $-354.4 *$ & $-343.3^{*}$ & $-332.2 *$ & 132.3 & 130.9 & 127.4 & -286.3 & -274.9 & -280.9 \\
\hline Log other income & $88.4^{* * *}$ & $86.8 * * *$ & $88.9 * * *$ & -22.6 & -22.3 & -24.4 & $76.0^{* *}$ & $73.5^{* *}$ & $76.2 * *$ \\
\hline Log wealth & $166.0 * * *$ & $165.5 * * *$ & $165.0 * * *$ & 19.2 & 19.3 & 20.9 & $197.0 * * *$ & $195.9 * * *$ & $196.4 * * *$ \\
\hline Spouse contributes to DC & 336.1 & 334.9 & 328.1 & 56.6 & 56.4 & 64.6 & 449.9 & 449.8 & 449.2 \\
\hline Short-tenure (tenure $<=4$ years) & -87.2 & -276.1 & -82.0 & $-359.7^{* *}$ & $-331.8 *$ & $-368.3 * *$ & $-452.5 *$ & $-676.6^{* *}$ & $-453.2 *$ \\
\hline Bottom earnings quintile & $-1289.6 * * *$ & $-1294.3^{* * *}$ & $-1464.7 * * *$ & $-1042.9 * * *$ & $-1042.2 * * *$ & $-1042.1 * * *$ & $-2479.8^{* * *}$ & ${ }^{k}-2487.9 * * *$ & $-2629.0 * * *$ \\
\hline 2nd earnings quintile & $-950.7 * * *$ & $-951.6 * * *$ & $-993.9 * * *$ & $-669.8 * * *$ & $-670.0 * * *$ & $-681.1 * * *$ & $-1858.1 * * *$ & * $-1857.3 * * *$ & $-1899.8 * * *$ \\
\hline 4th earnings quintile & $1256.3^{* * *}$ & $1260.3^{* * *}$ & $1378.6^{* * *}$ & $615.4^{* * *}$ & $614.2^{* * *}$ & $538.9 * * *$ & $1837.3^{* * *}$ & $1846.1^{* * *}$ & $1866.9 * * *$ \\
\hline Top earnings quintile & $5400.1 * * *$ & $5398.0 * * *$ & $5942.4^{* * *}$ & $3028.6^{* * *}$ & $3028.4^{* * *}$ & $2530.6^{* * *}$ & $8505.4^{* * *}$ & $8507.2^{* * *}$ & $8570.8^{* * *}$ \\
\hline Year 2008 & 62.3 & 65.6 & 40.5 & $-526.8^{* * *}$ & $-526.5 * * *$ & $-509.8 * * *$ & $-517.9 *$ & $-518.0 *$ & $-524.7 *$ \\
\hline Year 2010 & $-486.6^{* * *}$ & $-490.8^{* * *}$ & $-504.8 * * *$ & $-1144.7 * * *$ & $-1143.3^{* * *}$ & $-1126.0 * * *$ & $-1640.4^{* * *}$ & *-1650.4*** & $-1645.6 * * *$ \\
\hline Year 2012 & -129.9 & -139.4 & -161.0 & $-1376.1^{* * *}$ & $-1374.2 * * *$ & $-1346.5 * * *$ & $-1408.6^{* * *}$ & ${ }^{k}-1423.8^{* * *}$ & $-1414.6 * * *$ \\
\hline Automatic enrollment & $-1684.1 * * *$ & $-1844.5^{* * *}$ & $-913.2 * * *$ & 841.2*** & $865.8 * * *$ & 6.2 & $-914.0 * * *$ & $-1113.7 * * *$ & $-848.3 * *$ \\
\hline Automatic enrollment $*$ Short-tenure & & $823.7 * *$ & & & -125.3 & & & 1012.6 & \\
\hline Automatic enrollment $*$ Bottom quintile & & & 451.6 & & & 147.0 & & & 539.5 \\
\hline Automatic enrollment $* 2$ 2nd quintile & & & 201.9 & & & 79.2 & & & 182.8 \\
\hline Automatic enrollment $* 4$ th quintile & & & -499.6 & & & 355.1 & & & -126.9 \\
\hline \multirow[t]{2}{*}{ Automatic enrollment * Top quintile } & & & $-2248.0 * * *$ & & & $2152.7 * * *$ & & & -269.7 \\
\hline & $1321.5^{* * *}$ & $1344.3^{* * *}$ & $1348.6 * * *$ & 398.6 & 394.0 & 362.7 & $1745.7 * * *$ & $1783.6^{* * *}$ & $1750.4 * * *$ \\
\hline Pseudo $\mathrm{R}^{2}$ & 0.363 & 0.364 & 0.369 & 0.147 & 0.147 & 0.154 & 0.377 & 0.377 & 0.377 \\
\hline Number of observations & 5,019 & 5,019 & 5,019 & 4,278 & 4,278 & 4,278 & 4,158 & 4,158 & 4,158 \\
\hline
\end{tabular}

Notes: Sample includes workers under age 70 who are not self-employed and who report positive wages. Respondents are included in a plan if they report being

included and they or their employer contributes to their DC plan. Significance: *** $\mathrm{p}<0.01,{ }^{* *} \mathrm{p}<0.05,{ }^{*} \mathrm{p}<0.1$.

Source: Authors’ calculations from the 2006-2012 waves of the Health and Retirement Study. 
Table 8. OLS Regression of Contribution Rates among Workers under Age 70 Included in a DC plan

\begin{tabular}{|c|c|c|c|c|c|c|c|c|c|}
\hline \multirow[b]{2}{*}{ Variable } & \multicolumn{3}{|c|}{ Employee contribution } & \multicolumn{3}{|c|}{ Employer contribution } & \multicolumn{3}{|c|}{ Total contribution } \\
\hline & (1) & $(2)$ & (3) & (4) & (5) & (6) & (7) & $(8)$ & (9) \\
\hline [omitted group: <50] & & & & & & & & & \\
\hline Age $50-59$ & $0.734^{* *}$ & $0.754 * *$ & $0.738 * *$ & 0.176 & 0.156 & 0.135 & $1.045 *$ & $1.075 *$ & $1.017 *$ \\
\hline Age 60-69 & $1.190 * * *$ & $1.210 * * *$ & $1.195 * * *$ & 0.092 & 0.072 & 0.034 & $1.817 * * *$ & $1.846 * * *$ & $1.783^{* * *}$ \\
\hline Male & 0.243 & 0.245 & 0.239 & $0.525 * *$ & $0.526 * *$ & $0.544^{* *}$ & $0.655^{*}$ & $0.655^{*}$ & $0.665^{*}$ \\
\hline High school graduate & $0.842 * *$ & $0.831 * *$ & $0.855 * *$ & 0.024 & 0.034 & 0.016 & 0.880 & 0.863 & 0.875 \\
\hline Some college & $0.951 * * *$ & $0.942 * * *$ & $0.966 * * *$ & 0.359 & 0.367 & 0.331 & $1.214^{*}$ & $1.199 *$ & $1.199 *$ \\
\hline College & $1.433 * * *$ & $1.427 * * *$ & $1.447 * * *$ & 0.229 & 0.237 & 0.200 & $1.684^{* *}$ & $1.670^{* *}$ & $1.664^{* *}$ \\
\hline Black & -0.274 & -0.276 & -0.273 & 0.507 & 0.508 & 0.501 & 0.199 & 0.197 & 0.199 \\
\hline Other & 0.557 & 0.536 & 0.557 & 0.389 & 0.405 & 0.371 & $1.254^{*}$ & $1.230 *$ & $1.240 *$ \\
\hline In a coupled household & -0.435 & -0.425 & -0.432 & -0.079 & -0.085 & -0.078 & -0.662 & -0.653 & -0.662 \\
\hline Log other income & $0.149 * * *$ & $0.148 * * *$ & $0.150 * * *$ & 0.008 & 0.009 & 0.007 & $0.177 * * *$ & $0.175^{* * *}$ & $0.177 * * *$ \\
\hline Log wealth & $0.189 * * *$ & $0.189 * * *$ & $0.189 * * *$ & 0.001 & 0.001 & 0.002 & $0.261 * * *$ & $0.260 * * *$ & $0.262 * * *$ \\
\hline Spouse contributes to DC & 0.166 & 0.164 & 0.162 & 0.000 & -0.000 & 0.006 & 0.366 & 0.366 & 0.368 \\
\hline Short-tenure (tenure $<=4$ years) & -0.251 & $-0.422 *$ & -0.251 & -0.253 & -0.132 & -0.255 & -0.568 & $-0.747 *$ & -0.570 \\
\hline Bottom earnings quintile & -0.255 & -0.261 & -0.176 & 0.017 & 0.021 & -0.063 & -0.871 & -0.879 & -0.910 \\
\hline 2nd earnings quintile & $-0.990 * * *$ & $-0.992 * * *$ & $-1.026 * * *$ & $-0.594^{*}$ & $-0.595 *$ & $-0.838 * *$ & $-2.467 * * *$ & $-2.467 * * *$ & $-2.603 * * *$ \\
\hline 4th earnings quintile & $0.711^{* * *}$ & $0.713 * * *$ & $0.756 * *$ & -0.243 & -0.248 & -0.431 & -0.101 & -0.094 & -0.163 \\
\hline Top earnings quintile & $1.499 * * *$ & $1.496 * * *$ & $1.601 * * *$ & -0.082 & -0.082 & $-0.573 *$ & 0.477 & 0.478 & 0.175 \\
\hline Year 2008 & -0.043 & -0.040 & -0.048 & $-0.933 * * *$ & $-0.932 * * *$ & $-0.918 * * *$ & -0.621 & -0.621 & -0.613 \\
\hline Year 2010 & $-0.743 * * *$ & $-0.747 * * *$ & $-0.746 * * *$ & $-1.955 * * *$ & $-1.949 * * *$ & $-1.944 * * *$ & $-2.609 * * *$ & $-2.617 * * *$ & $-2.601 * * *$ \\
\hline Year 2012 & $-0.494 * *$ & $-0.502 * *$ & $-0.501 * *$ & $-2.232 * * *$ & $-2.224 * * *$ & $-2.213 * * *$ & $-2.359 * * *$ & $-2.370 * * *$ & $-2.346 * * *$ \\
\hline Automatic enrollment & $-2.599 * * *$ & $-2.743 * * *$ & $-2.421 * * *$ & $1.089 * * *$ & $1.196 * * *$ & -0.052 & $-1.609 * * *$ & $-1.769 * * *$ & $-2.234 * * *$ \\
\hline Automatic enrollment * Short-tenure & & 0.744 & & & -0.540 & & & 0.806 & \\
\hline Automatic enrollment $*$ Bottom quintile & & & -0.303 & & & 0.487 & & & 0.254 \\
\hline Automatic enrollment $* 2$ nd quintile & & & 0.155 & & & 1.120 & & & 0.625 \\
\hline Automatic enrollment $* 4$ th quintile & & & -0.188 & & & 0.867 & & & 0.302 \\
\hline Automatic enrollment $*$ Top quintile & & & -0.425 & & & $2.168 * * *$ & & & 1.343 \\
\hline Pseudo $\mathrm{R}^{2}$ & 0.116 & 0.116 & 0.115 & 0.022 & 0.022 & 0.024 & 0.061 & 0.061 & 0.061 \\
\hline Number of observations & 4,978 & 4,978 & 4,978 & 4,266 & 4,266 & 4,266 & 4,140 & 4,140 & 4,140 \\
\hline
\end{tabular}

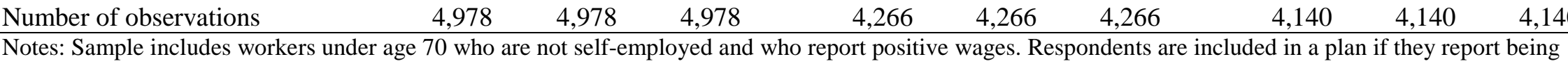

included and they or their employer contributes to their DC plan. Significance: ${ }^{* * *} \mathrm{p}<0.01,{ }^{* *} \mathrm{p}<0.05,{ }^{*} \mathrm{p}<0.1$

Source: Authors' calculations from the 2006-2012 waves of the Health and Retirement Study. 
Figure 1. Distribution of Employee Contribution Amounts among Workers Ages 55 to 69 Included in a DC Plan, by Auto-enrollment Status

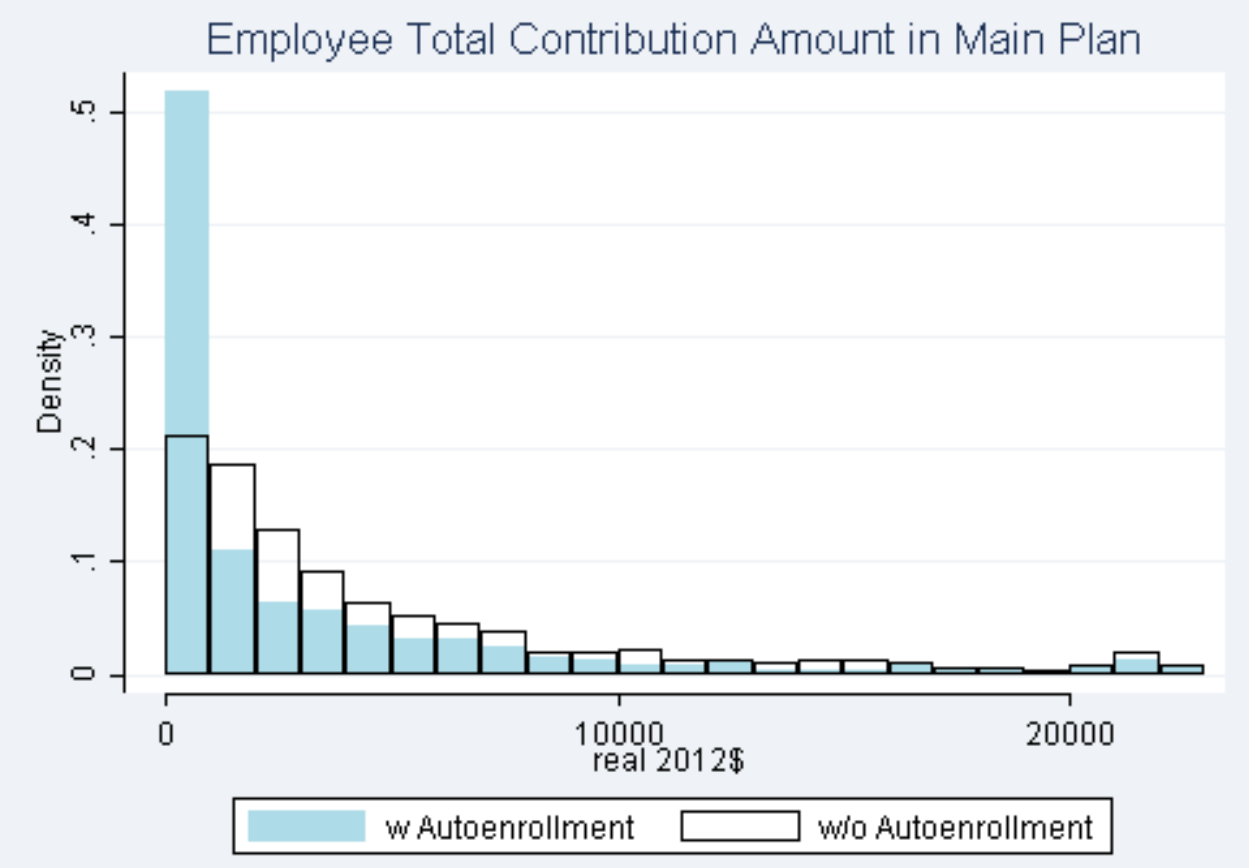

Notes: Sample includes workers ages 55 to 69 who are not self-employed and who report positive wages.

Respondents are included in a plan if they report being included and they or their employer contributes to their DC plan.

Source: Authors' calculations from the 2006-2012 waves of the Health and Retirement Study. 
Figure 2. Distribution of Employer Contribution Amounts among Workers Ages 55 to 69 Included in a DC Plan, by Auto-enrollment Status

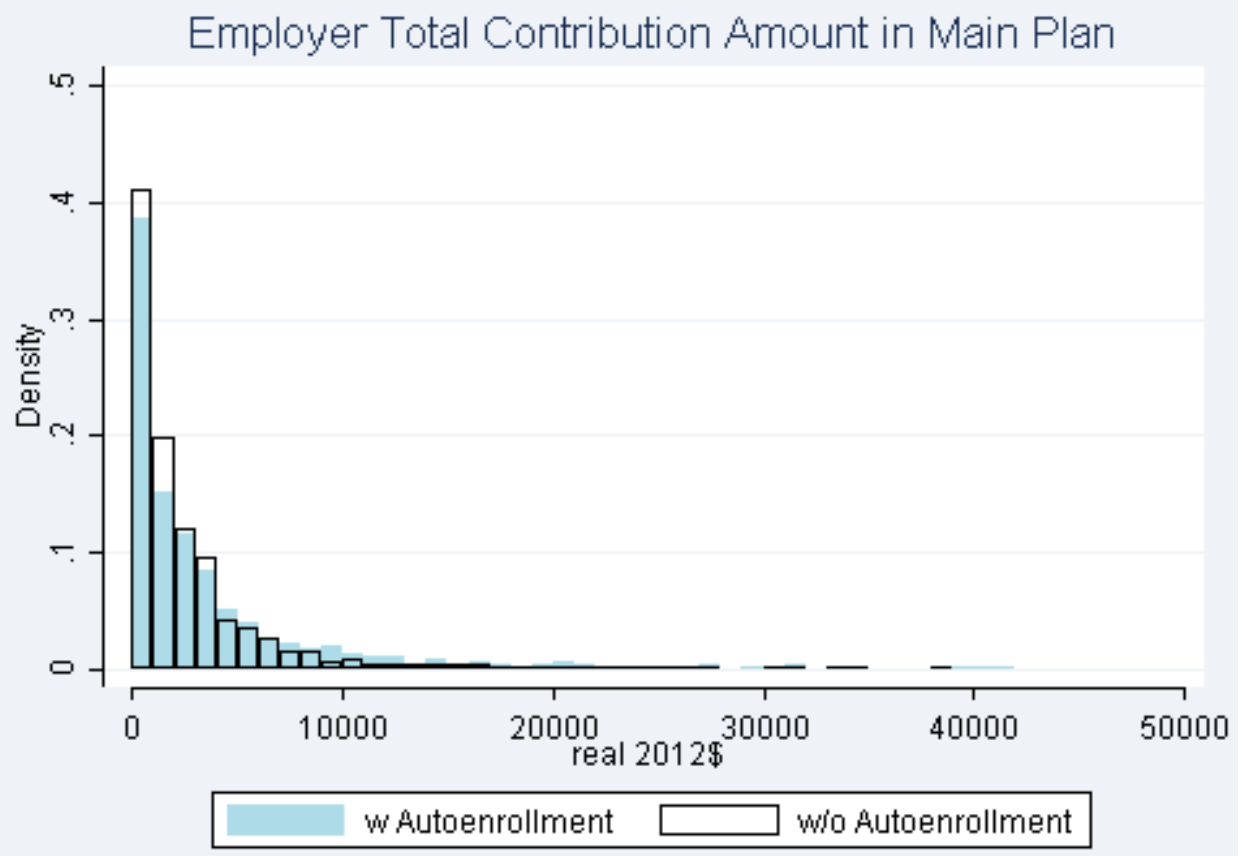

Notes: Sample includes workers ages 55 to 69 who are not self-employed and who report positive wages.

Respondents are included in a plan if they report being included and they or their employer contributes to their DC plan.

Source: Authors' calculations from the 2006-2012 waves of the Health and Retirement Study. 
Figure 3. Distribution of Total Contribution Amounts among Workers Ages 55 to 69 Included in a DC Plan, by Auto-enrollment Status

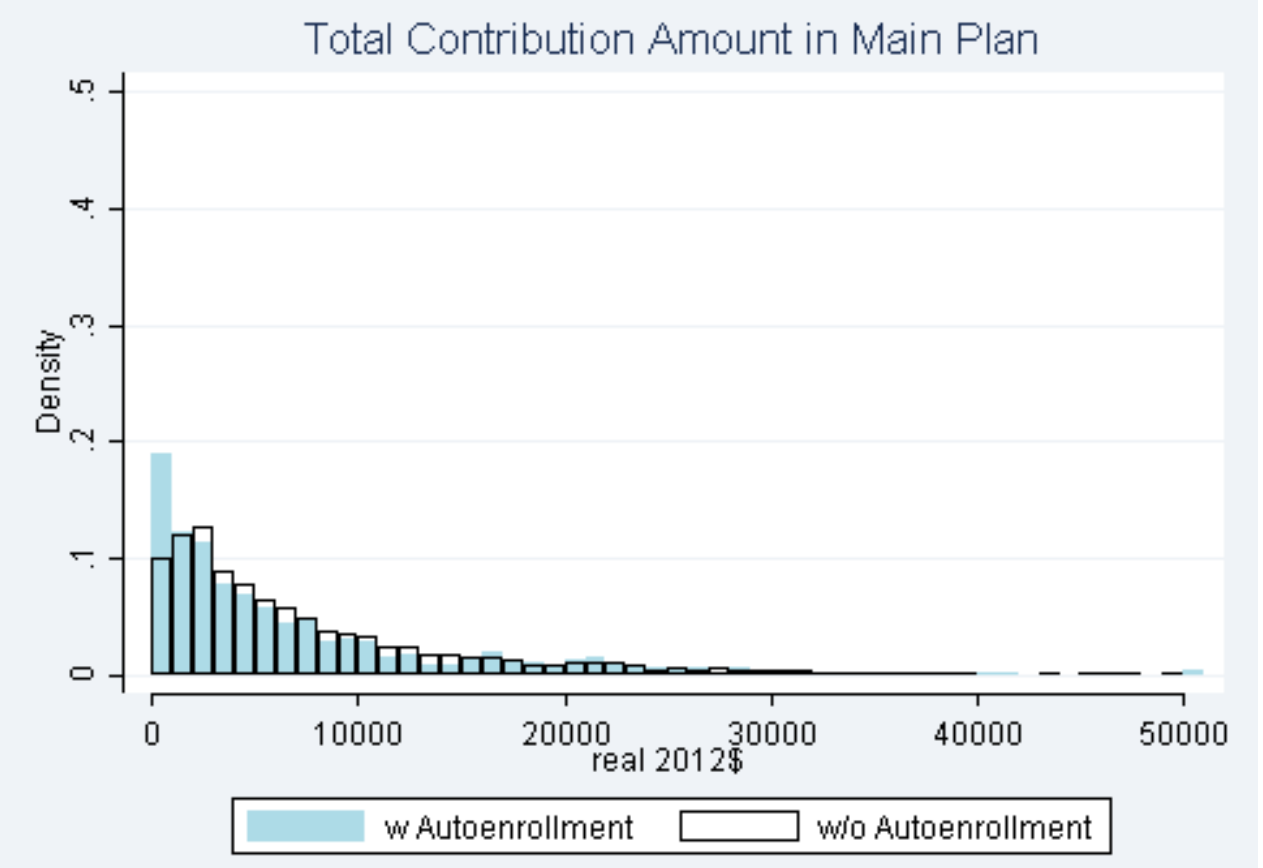

Notes: Sample includes workers ages 55 to 69 who are not self-employed and who report positive wages.

Respondents are included in a plan if they report being included and they or their employer contributes to their DC plan.

Source: Authors' calculations from the 2006-2012 waves of the Health and Retirement Study. 
Figure 4. Distribution of Employee Contribution Rates among Workers Ages 55 to 69 Included in a DC Plan, by Auto-enrollment Status

\section{Employee Total Contribution Percent in Main Plan}

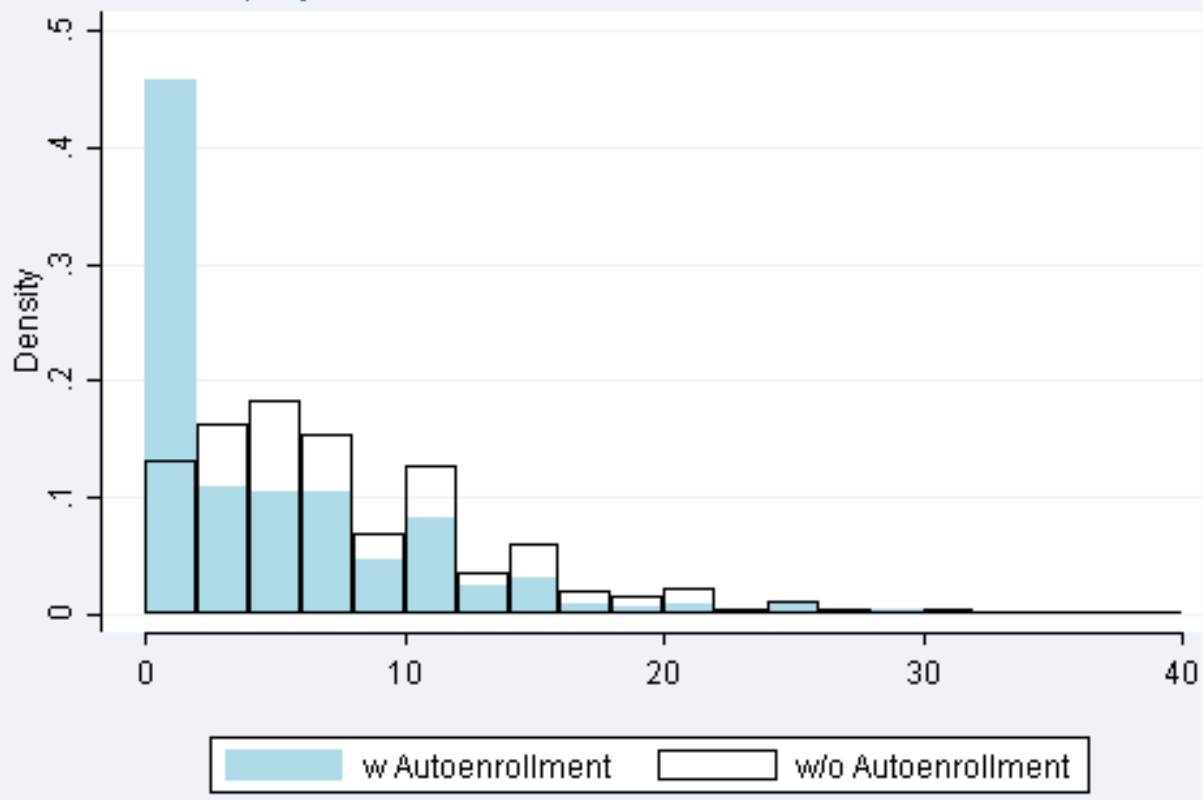

Notes: Sample includes workers ages 55 to 69 who are not self-employed and who report positive wages.

Respondents are included in a plan if they report being included and they or their employer contributes to their DC plan.

Source: Authors’ calculations from the 2006-2012 waves of the Health and Retirement Study. 
Figure 5. Distribution of Employer Contribution Rates among Workers Ages 55 to 69 Included in a DC Plan, by Auto-enrollment Status

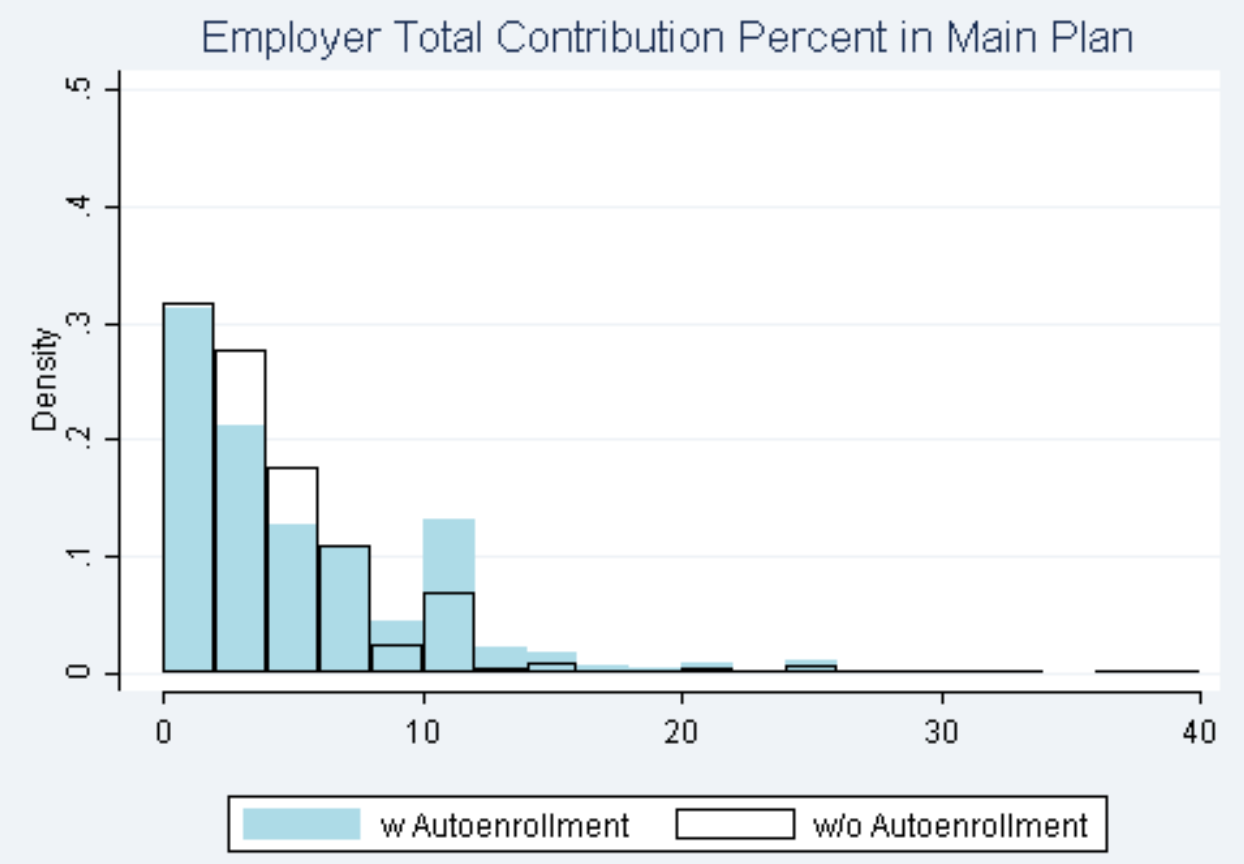

Notes: Sample includes workers ages 55 to 69 who are not self-employed and who report positive wages.

Respondents are included in a plan if they report being included and they or their employer contributes to their DC plan.

Source: Authors' calculations from the 2006-2012 waves of the Health and Retirement Study. 
Figure 6. Distribution of Total Contribution Rates among Workers Ages 55 to 69

Included in a DC Plan, by Auto-enrollment Status

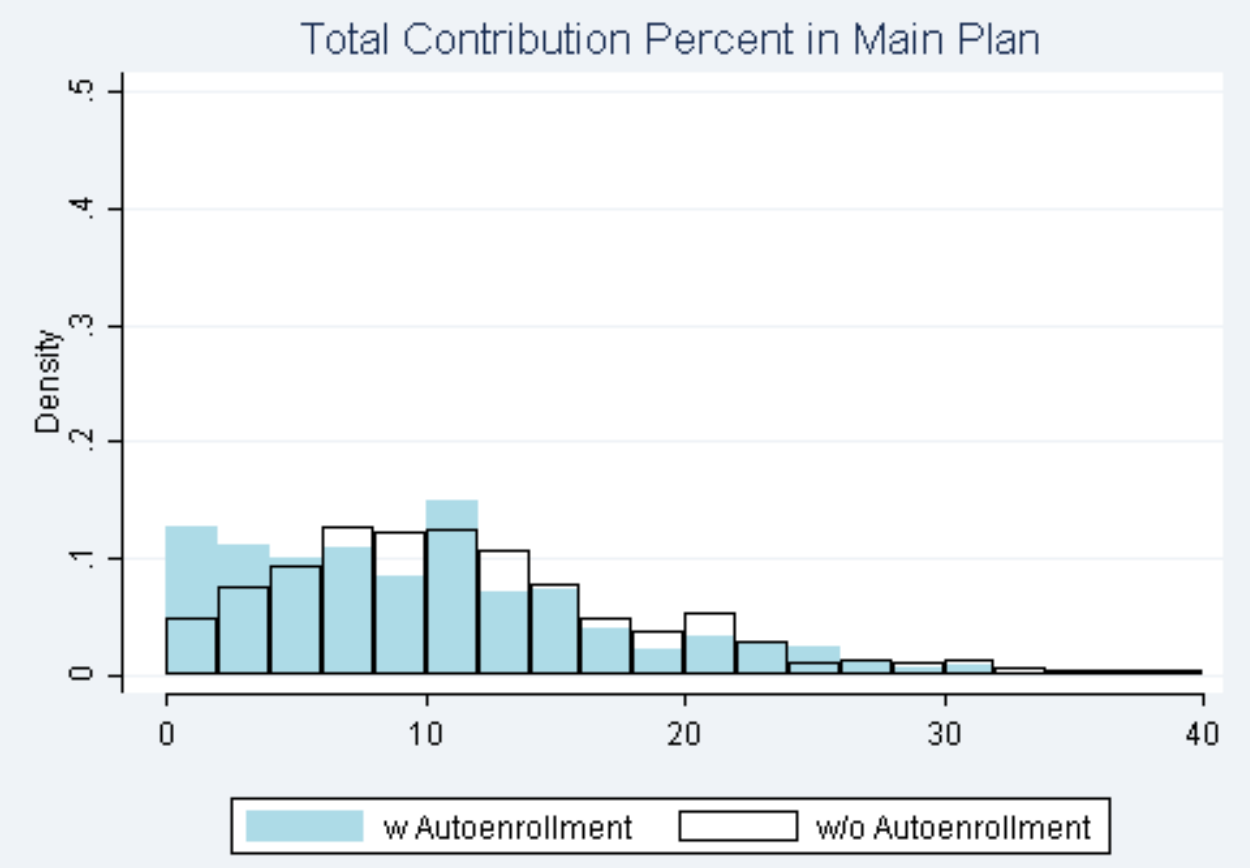

Notes: Sample includes workers ages 55 to 69 who are not self-employed and who report positive wages.

Respondents are included in a plan if they report being included and they or their employer contributes to their DC plan.

Source: Authors' calculations from the 2006-2012 waves of the Health and Retirement Study. 


\section{RECENT WORKING PAPERS FROM THE CENTER FOR RETIREMENT RESEARCH AT BOSTON COLLEGE}

Evidence of Increasing Differential Mortality: A Comparison of the HRS and SIPP Barry P. Bosworth and Kan Zhang, July 2015

Slowed or Sidelined? The Effect of "Normal" Cognitive Decline on Job Performance Among the Elderly

Anek Belbase, Mashfiqur R. Khan, Alicia H. Munnell, and Anthony Webb, June 2015

Does Social Security Continue to Favor Couples?

Nadia S. Karamcheva, April Yanyuan Wu, and Alicia H. Munnell, June 2015

Sources of Increasing Differential Mortality Among the Aged by Socioeconomic Status Barry P. Bosworth, Gary Burtless, and Kan Zhang, June 2015

Do Retired Americans Annuitize Too Little? Trends in the Share of Annuitized Income Barry P. Bosworth, Gary Burtless, and Mattan Alalouf, June 2015

Impact of the Financial Crisis on Long-Term Growth

Barry P. Bosworth, June 2015

Post-War Trends in Labor Income in the Social Security Earnings Records Gary Burtless and Kan Zhang, June 2015

Improving Employees' Life and Disability Insurance Benefit Decisions: Results of an Employer Survey

Anek Belbase, Norma B. Coe, and Matthew S. Rutledge, June 2015

Overcoming Barriers to Life Insurance Coverage: A Behavioral Approach

Anek Belbase, Norma B. Coe, and April Yanyuan Wu, June 2015

How Do People Decide on Life Insurance and Long-Term Disability Insurance Coverage? Norma B. Coe and Anek Belbase, June 2015

What Do Subjective Assessments of Financial Well-Being Reflect?

Steven A. Sass, Anek Belbase, Thomas Cooperrider, and Jorge D. Ramos-Mercado, March 2015

The Impact of Leakages from 401(k)s and IRAs

Alicia H. Munnell and Anthony Webb, February 2015

Recruiting and Retaining High-Quality State and Local Workers: Do Pensions Matter? Alicia H. Munnell, Jean-Pierre Aubry, and Geoffrey T. Sanzenbacher, January 2015

All working papers are available on the Center for Retirement Research website (http://crr.bc.edu) and can be requested by e-mail (crr@bc.edu) or phone (617-552-1762). 